\title{
Research on Mobile Teaching Reform in Chinese Universities Based on Online Courses*
}

\author{
Qi Zhong \\ Qilu Normal University \\ Jinan, China 250013
}

\author{
Ying Wei \\ Qilu Normal University \\ Jinan, China 250013
}

\begin{abstract}
Starting from the current phenomenon that there are a large number of college students in China, this paper uses the current new mobile teaching model advocated to tackle the problems of large scale and poor effect in the classroom of university, analyzes the challenges and problems that Chinese college students of, college teachers and network course platform are facing, and puts forward corresponding countermeasures based on practical experience. This paper innovatively proposes a reasonable solution to the total score composition in mobile teaching; recommends that total volume of each homework per week should be controlled within 1 hour; proposes to establish teaching assistant system by using mobile teaching course. The "assistant" can be a teacher, or a graduate student, or even an ordinary student with high computer skills. This paper aims to strengthen the construction of network courses in colleges and universities, publicize the mobile teaching experience, and provide advice on the use of mobile teaching for most college students, training experts and educators in primary and secondary schools at home and abroad.
\end{abstract}

Keywords-on-line courses; mobile learning; college students; China; Chinese university

\section{INTRODUCTION}

High-level resources of human talents are the internal impetus for the development of enterprises, as well as an important resource for the development of a country [1]. In recent years, China has been committed to turning demographic quantity dividend into demographic quality dividend. There will be a new dividend in China, but also the new number of demographic dividend is amazing, in which higher education plays an important role [2]. The important content of college education reform is to improve students' practical ability and comprehensive quality [3]. The use of mobile teaching methods to solve the problem of large-scale classroom teaching is a trend in the development of informatization in the world, and China's educational circles have paid more attention to it in recent years. The number of graduates from ordinary universities in China has increased from 1.14 million in 2001 to 7.65 million in 2016, an increase of nearly 7 times. According to the Quality Report on Chinese Higher Education issued by Ministry of Education of the People s Republic of China, the number of college students in China reached 37 million in 2015, equivalent to Canada's population, and ranked first in the world[4].

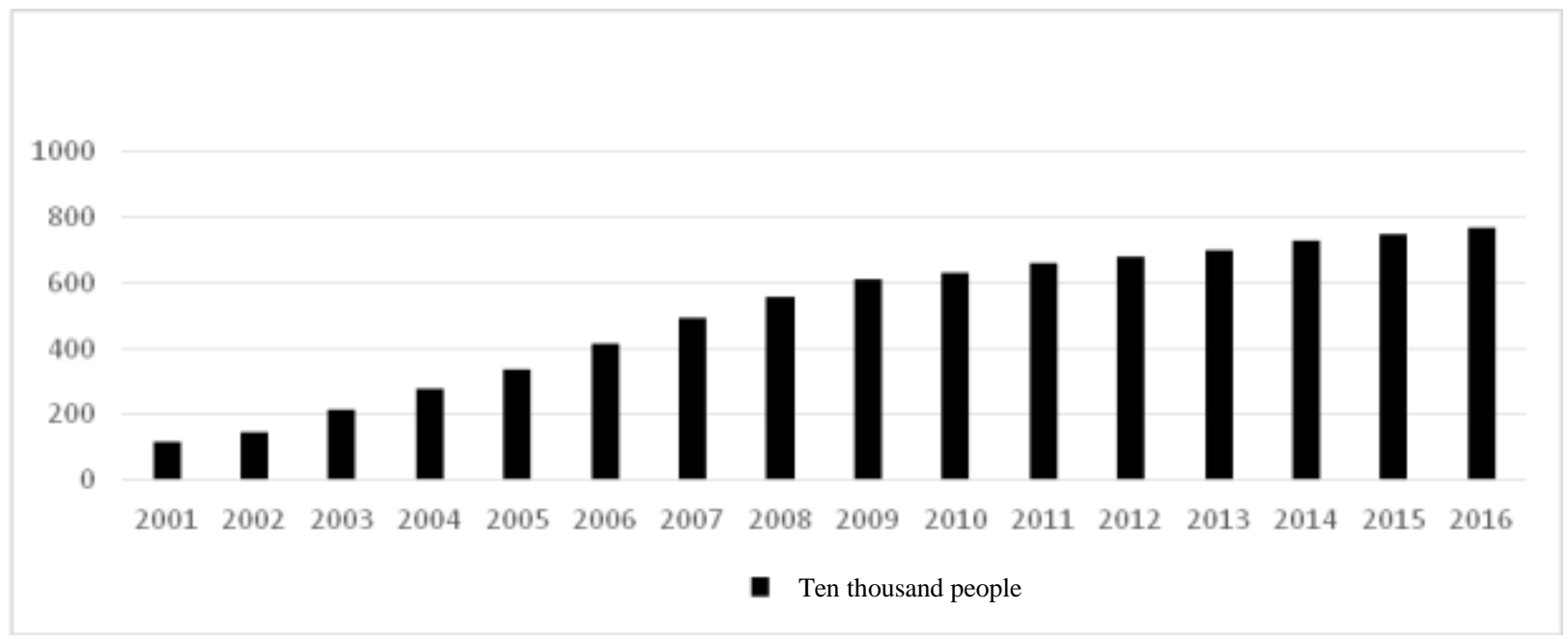

Fig. 1. The number of Chinese college graduates in 2001-2015 (ten thousand people).

*This research was financially supported by the second batch of industry-academy cooperation and jointly cultivating students project (201702023070) of Chinese Ministry of Education in 2017, and online open course project International Trade (wlkc201615) and Political Economy (wlkc201716) in Qilu Normal University.
Data source: official website of Ministry of Education of the People s Republic of China: www.moe.gov.cn

There were 17 universities in China with a total number of college students over 50 thousand in 2017. Zhengzhou 
University has more than 72.6 thousand full-time students, and Jilin University ranked second in number of Chinese college students list with an enrollment of 69.6 thousand. Huazhong University of Science and Technology, Sichuan University, Shandong University and Wuhan University ranked third, fourth, sixth and seventh respectively in the list of the number of college students in China. Over the years, the problem of the decline in quality of higher education caused by insufficient student-faculty ratio and large scale of the classroom has disturbed Chinese universities and their teachers.

TABLE I. RANKING LIST OF THE NUMBER OF FULL-TIME STUDENTS IN CHINA IN 2017

\begin{tabular}{|c|c|c|c|}
\hline No & Name of University & $\begin{array}{l}\text { The Number of } \\
\text { Students }\end{array}$ & City \\
\hline 1 & Zhengzhou University & $\begin{array}{l}\text { More than } 72.6 \\
\text { thousand students }\end{array}$ & Zhengzhou \\
\hline 2 & Jilin University & $\begin{array}{l}\text { More than } 69.6 \\
\text { thousand students }\end{array}$ & Changchun \\
\hline 3 & $\begin{array}{l}\text { Huazhong University of } \\
\text { Science and Technology }\end{array}$ & $\begin{array}{l}\text { More than } 61.7 \\
\text { thousand students }\end{array}$ & Wuhan \\
\hline 4 & Sichuan University & $\begin{array}{l}\text { More than } 60 \\
\text { thousand students }\end{array}$ & Chengdu \\
\hline 5 & He'nan University & $\begin{array}{l}60 \text { thousand } \\
\text { students }\end{array}$ & Kaifeng \\
\hline 6 & Shandong University & $\begin{array}{l}\text { More than } 59.5 \\
\text { thousand students }\end{array}$ & Jinan \\
\hline 7 & Wuhan University & $\begin{array}{l}\text { More than } 56.8 \\
\text { thousand students }\end{array}$ & Wuhan \\
\hline 8 & Central South University & $\begin{array}{l}\text { More than } 55.7 \\
\text { thousand students }\end{array}$ & Changsha \\
\hline 9 & $\begin{array}{l}\text { Wuhan University of } \\
\text { Technology }\end{array}$ & $\begin{array}{l}\text { More than } 54 \\
\text { thousand students }\end{array}$ & Wuhan \\
\hline 10 & $\begin{array}{l}\text { Harbin Institute of } \\
\text { Technology }\end{array}$ & $\begin{array}{l}\text { More than } 53.3 \\
\text { thousand students }\end{array}$ & Harbin \\
\hline 11 & Guizhou University & $\begin{array}{l}\text { More than } 53.2 \\
\text { thousand students }\end{array}$ & Guiyang \\
\hline 12 & $\begin{array}{l}\text { North China University of } \\
\text { Science and Technology }\end{array}$ & $\begin{array}{l}\text { More than } 52 \\
\text { thousand students }\end{array}$ & Tangshan \\
\hline 13 & Nanchang University & $\begin{array}{l}\text { More than } 51.3 \\
\text { thousand students }\end{array}$ & Nanchang \\
\hline 14 & Sun Yat-sen University & $\begin{array}{l}\text { More than } 50.9 \\
\text { thousand students }\end{array}$ & Guangzhou \\
\hline 15 & Chongqing University & $\begin{array}{l}\text { More than } 50 \\
\text { thousand students }\end{array}$ & Chongqing \\
\hline 16 & Southwest University & $\begin{array}{l}\text { More than } 50 \\
\text { thousand students }\end{array}$ & Chongqing \\
\hline 17 & Suzhou University & $\begin{array}{l}\text { More than } 50 \\
\text { thousand students }\end{array}$ & Suzhou \\
\hline 18 & Jinan University & $\begin{array}{l}\text { More than } 48.1 \\
\text { thousand students }\end{array}$ & Guangzhou \\
\hline 19 & He'nan Normal University & $\begin{array}{l}\text { More than } 48 \\
\text { thousand students }\end{array}$ & Xinxiang \\
\hline 20 & Zhejiang University & $\begin{array}{l}\text { More than } 47.3 \\
\text { thousand students }\end{array}$ & Hangzhou \\
\hline 21 & $\begin{array}{lll}\text { Shanghai Jiao } & \text { Tong } \\
\text { University } & & \\
\end{array}$ & $\begin{array}{l}\text { More than } 47.2 \\
\text { thousand students }\end{array}$ & Shanghai \\
\hline 22 & $\begin{array}{l}\text { Southwest } \\
\text { University }\end{array}$ & $\begin{array}{l}\text { More than } 46.8 \\
\text { thousand students }\end{array}$ & Chengdu \\
\hline
\end{tabular}

\section{TREND OF Mobile TEACHING Reform IN CHINA}

In 2008, the MOOC (Massive Open Online Course), jointly proposed by the Manager of Web Communication and Innovations in the University of Prince Edward Island and the senior researcher in National Institute for Technology in Liberal Education, brought Chinese educators a solution to the problem. Many universities and experts in China have also noticed the advantages of this online course. The data show that since 2013, there emerged a number of influential MOOC platforms, such as " $i$ Course" and "Chinese university's MOOC" of Higher Education Press, "XuetangX" of Tsinghua University, "Chinese MOOCS" of Peking University, "CNMOOC" of Shanghai Jiao Tong University, "UOOC Online" of Shenzhen University, and so on, and their development has exerted an important effect in improving Chinese people's level of higher education. On the one hand, these websites generally offer free course video, syllabus, exercises, teaching plans and reference materials to the registered users for free or almost for free. On the other hand, the lecturer has rich teaching experience, good quality and content. However, the early teaching videos were recorded roughly, directly showing the daily teaching process in the university classroom. With the establishment of professional recorded broadcast hall in universities, teaching videos have become more exquisite, and then round-table discussions, onsite operations and other teaching modes have emerged. Certainly, the number of curricular teams has generally risen while the overall quality of the curriculum has increased.

At present, the Ministry of Education of China vigorously promotes the "problem-based" teaching method and increasing the weight of practical teaching. Chinese universities are required to develop heuristic, inquiry, discussion and participative classroom teaching. The new teaching idea is inseparable from the support of modern science and technology, and the mobile teaching mode has become popular in China. Yu Shengquan (2013), Dean of School of Educational Technology of Beijing Normal University, believed that mobile devices are finding their own way of development, that is, entering the classroom from the pocket of the students, and we must ensure that educational practices can include these vital technologies [5]. Xu Weishuang (2017) put forward that the use of new teaching methods that are closely integrated with informationization, such as mixed method of teaching, behavioral teaching method, and interactive teaching method, can guarantee the cultivation of talents [6]. Since 2014 , the Ministry of Education of China has organized well-known enterprises to cooperate with universities for industry-academy cooperation to jointly cultivate the students. 33 enterprises including Microsoft, Google, Chaoxing, Intel, Baidu, Alibaba and other enterprises have worked together with many colleges and universities to integrate mobile teaching based on online courses into daily teaching. This kind of teaching reform has brought about some problems and challenges to teachers, college students and network platforms.

\section{Challenges IN THE REFORM OF MobILE TEACHING IN COLLEGES AND UNIVERSITIES}

\section{A. Teachers}

First, teachers are faced with the challenge of the increased workload. The mobile teaching will break the traditional lesson preparation mode and teaching mode. What is obviously different from Russia is that Chinese universities purchase and 
distribute textbooks of each course for teachers and students every semester. In the traditional teaching mode, the university teachers will compile their own teaching plans by referring to the content of different textbooks and academic progress, and searching for news cases and various exercises. In class, the teacher mainly focuses on the syllabus requirements to implement the teaching materials combining with explaining and practicing. In the case of using the mobile teaching platform to assist the teaching, there is an additional online class-building task before the start of the class. What's more, various functions, including calling the roll, publishing assignments, and initiating discussions by using PC, are added to the class. Therefore, the second biggest challenge is teachers' discomfort with the functions of the network platform due to the lack of training or inadequate experience. Third, teachers are faced with the challenge of insufficient knowledge reserves. With the help of the function of network platform, the number of people participating in a class discussion has increased significantly. The convenience of obtaining information on the Internet makes the students have diversified answers. Therefore, teachers must have solid basic knowledge and broad knowledge to tackle all kinds of problems in the classroom.

\section{B. Students}

First, students are faced with the challenge of increased amount of knowledge. The latest mobile learning platform can provide users with diversified services. For example, the Chaoxing platform, an online course, that may include text narration, picture display, connection to book pages, audio and video presentations, slide shows, animation presentations, and other contents from various channels. The amount of information and novelty are much higher than that of paper textbooks. Registered users can also access electronic newspapers, periodicals, monographs and so on by themselves. Therefore, students will get much knowledge. Second, the learning expenditure of students increases. The use of network platform requires that students have to bring their own smart phones. About $\$ 200$ is needed if a student buy an ordinary Chinese phone, and a $\$ 500-600$ of mobile phone is needed if a student wants to make the answer faster in class. In the meantime, Internet expense becomes a necessary expense. No matter whether students use computers or mobile phones, they can participate in class discussions, view course pages, and complete homework assignments in a networking state. There are three major mobile phone operators in China, namely, Mobile, China Unicom and Telecom. The amount 1G Mobile card and Unicom card used by students is \$5 ( $¥ 30$ ) per month. Next, adapting to the functions of the network platform is also a challenge for students. What is different from teachers is that students' discomfort with the platform is mostly related to time. According to the student's inquiries during the lecture, it is generally reflected that the deadline for homework and tests is often forgotten, and message omissions due to infrequent login platforms also occur. Therefore, it is necessary for teachers to remind students of the cut-off date of mobile teaching face to face in class. Even so, adapting to various platforms and their functions is a major challenge for students.

\section{Platforms}

First, the mobile teaching platform faces technical challenges. Preventing hacker attacks and customer information leakage and increasing website traffic limit becomes the important aspects to guarantee China's cyber security. Whether the largest online shopping platform, Taobao, or train ticket website in China, they all happen to the phenomenon that the user can not open the website due to simultaneous logging. As a website that serves classroom teaching, it is inevitable that many people will log in at the same time, so the biggest challenge of the platform is to ensure the smooth use of the user. The next is the problem of customer service. Teachers and students who do not adapt to the platform need the help of customer service. Although the major platforms provide some customer service, customer service time and service speed are limited, especially night service. The third is the platform function. At present, there are many learning platforms, and they generally have functions of video explanation, question bank, and discussion. The costs will increase with the more attention paid to software details, enterprises, such as Baidu, Chaoxing, Tencent and so on, all attach great importance to the development of platform functions. This is because the functional advantages determine the number of users and then determine the success or failure of the enterprise. Therefore, the mobile teaching platform faces the challenge of $R \& D$ and service in the competition

\section{THE PROBLEMS AND COUNTERMEASURES IN THE PRACTICE OF MOBILE TEACHING REFORM}

\section{A. Problem of Student Achievement}

At the end of the 20th century, the results of all courses for Chinese college students shall be based on the final test. After many years of education reform, universities generally allow the usual performance to occupy a certain proportion, for example, a university permits that the usual performance can account for $30 \%$ in the percentage of total scores. Many experts think that increasing the weight of usual performance in university course assessment is conducive to improving the effectiveness of classroom teaching [7]. As a result, the usual performance in the current popular online course has a high proportion. For example, the default total performance composition of general courses on Chaoxing platform is shown in "Table II".

TABLE II. COMPOSITION OF SYSTEM DEFAUlT OF TOTAL SCORE IN CHAOXING ERYA

\begin{tabular}{|c|c|c|c|c|}
\hline $\begin{array}{c}\text { Course video } \\
40 \%\end{array}$ & $\begin{array}{c}\text { Chapter test } \\
20 \%\end{array}$ & $\begin{array}{c}\text { Number of visits } \\
10 \%\end{array}$ & $\begin{array}{c}\text { Homework } \\
15 \%\end{array}$ & $\begin{array}{c}\text { Exam } \\
15 \%\end{array}$ \\
\hline
\end{tabular}

It is easy to see that the proportion of usual performance in the default total score is up to $85 \%$, and the course video and the number of visits account for $50 \%$ of the total score. It is very likely that some students will get a full score by watching the video of the course and clicking on the course page. After participating in a little course, they can successfully pass the exam by 60 points. This problem will lead to that the training for some students can not achieve the expected requirements. Therefore, this problem can be tackled by increasing the proportion of final exam grade or requiring the students to 
participate in the final exam under the circumstance that the proportion of final exam grade accounts a low percentage and rejecting those students who cannot reach certain scores. Chinese educational institutions can also learn from the experience of Europe and America, increase oral test while taking the written exam, comprehensively urge students to learn, and strictly control the leaning quality of student.

\section{B. Problem of Learning Time}

Online courses make students inseparable from PC, but watching a mobile phone or computer for a long time can cause a lot of harm to the human body [8]. Based on the survey of Li Ting (2017), only 1/3 students can persist in learning every day, that is to say, there is a discontinuity in mobile learning. Most of the students' English mobile learning is carried out after class and in informal time, and $68.8 \%$ of students chose to conduct active mobile learning after class [9]. According to the author's inquiry on students, the generally acceptable maximum mobile learning time is 1-2 hours/day. It is usually $8-10$ courses per semester, in this way, it is advisable to limit the total amount of homework of each course to one hour per week.

\section{Problem of Teaching Assistant System}

The lowest level of professional and technical qualifications for Chinese college teachers is the teaching assistant, and his responsibility is to assist teaching. Most teachers lecture independently in traditional teaching, and often assistants only help teachers who are very old or have difficulties. In the previous narrative, we have analyzed that the breaking of the traditional teaching model by integrating the network into classroom teaching will multiply the workload of teachers. The PC operation in class is often distracting, and the problem that teachers and students do not adapt to the platform also needs someone to help solve it. Therefore, the establishment of teaching assistant system and finding someone to assist in teaching will reduce the classroom pressure of the instructors. Certainly, the person is not necessarily the assessed "teaching assistant", but must be the "teaching assistant" of the class. He can be a teacher, or a graduate student, or even a student in a class with higher computer skills.

\section{CONCLUSION}

Practice has proved that the implementation of mobile teaching is a realistic choice to solve the big class size and decline of teaching quality in Chinese universities, as well as an effective way for governments all over the world to solve the insufficient teaching resources in higher education, to popularize higher education in an all-round way and to improve the quality of the population. In the specific practice and experiment, college teachers, university students, and technology providers all are faced with a series of challenges, and also have different problems. By increasing the using experience of teachers and students, adding a teaching assistant system, rationally allocating total scores, controlling the learning length of college students and other countermeasures, the mobile teaching will be effectively popularized in China, and become more popular in the world.

\section{REFERENCES}

[1] Li Jian,Guo Ying, A Study on the Risk Assessment System of Talent Drain in Enterprises, Journal of Lanzhou University(Social Sciences), vol. 42, pp. 120-123, 2014.

[2] Li Yining, Ten Sharp Issues Chinese Economy Face, Textile Science Research, vol. 10, pp. 18-21, 2017.

[3] Hao Kening, Practice and Thinking on the Reform of Training Pattern of Professional Marketing Talents, Journal of Qilu Normal University, vol. 3, pp. 5-9, 2013.

[4] Official Website of Ministry of Education of the People s Republic of China: www.moe.gov.cn. www.moe.gov.cn

[5] Yu Shengquan, From Mobile Learning to Ubiquitous Learning, China Education Network, vol. 6, pp. 41, 2013.

[6] $\mathrm{Xu}$ Weishuang.Research on the Revision of Talent Cultivation Plan for Application-oriented Universities Based on Vocational Ability, Journal of Chifeng University (Natural Science Edition), vol. 33, pp. 198-200, 2017.

[7] Zhao Juan.An Analysis of Increasing the Weight of Usual Performance in the Assessment of University Courses, Asia-Pacific Education, vol. 28, pp. 267-268, 2015.

[8] Chen Xingyu, Zhang Chunyong, Investigation on the Harm of Mobile Phone to College Students in the Internet Age: Taking Yunnan Agricultural University as an Example, Journal of Yunnan Agricultural University (Social Science), vol. 9, pp. 96-100, 2015.

[9] Li Ting, Research on the Current Situation and Countermeasures of College Students' Mobile Learning - A Case Study of A College Students' English Learning[D].Master's Thesis of Central China Normal University, 2017. 